\title{
Next-Generation Bioacoustic Analysis Software
}

\author{
David K. Mellinger \\ Oregon State University \\ 2030 SE Marine Science Drive \\ Newport, OR 97365, USA \\ phone: (541) 867-0372 fax: (541) 867-3907 email: David.Mellinger@oregonstate.edu \\ Award Number: N00014-10-1-0534 \\ http://www.bioacoustics.us/ishmael.html
}

\section{LONG-TERM GOALS}

In the past two decades, awareness has grown that acoustic methods are often the best means for studying and monitoring marine mammals. Acoustic methods, for instance, have long been used for detection and study of sperm whales, in part because of the difficulty of visual detection: Visual surveys have been estimated to miss $38 \%$ of sperm whales that are on a ship's trackline (Barlow and Rankin 2004), and more at greater distances from the trackline. Other species are similar or worse; for instance, it is estimated that approximately $85 \%$ of Cuvier's beaked whales on the trackline are missed with visual scanning (J. Barlow, pers. comm). Acoustic methods, in contrast to visual ones, function well in darkness, fog, high sea states, and other inclement viewing conditions. Via the use of autonomous recorders, acoustic methods can also be used in remote or inhospitable areas (Širović et al. 2004, Mellinger et al. 2008) where visual monitoring would be impracticable or impossible. Software tools are needed for analyzing such data sets, even for such simple tasks as manually scanning spectrograms to find calls of interest. Acoustic localization of calling animals is often performed; whether estimates are in one dimension (bearing), two (X-Y position), or three (X-Y-Z position), analysis software is necessary. Marine mammal acoustic data is often collected in very large data sets, necessitating automated methods for data analysis. For instance, AURAL autonomous recorders (Multi-Électronique, Inc.) operate at a sample rate of $32 \mathrm{kHz}$, so that a one-year data set is 2 terabytes (TB) in size. Another type of autonomous recorder, the HARP (Wiggins 2003; J. Hildebrand, pers. comm.), operates at even higher sample rates - up to $200 \mathrm{kHz}$ - making a one-year data set $12.6 \mathrm{~TB}$ in size. Automation tools are clearly needed for data sets of this scale.

Starting in 2000, ONR funded the development of one such tool, Ishmael (Mellinger 2001). It is a userfriendly bioacoustic analysis package for Windows. It includes displays of sound waveforms and spectrograms, recording capability for real-time input, several methods for acoustic localization, beamforming, several methods for automatic call recognition, and a sound annotation facility. Ishmael is aimed at users wishing to analyze large volumes of data quickly and easily. Ishmael quickly became popular, with thousands of downloads by users; a large proportion those downloads were in active use, and a survey in 2005 showed that $46 \%$ of respondents use it regularly. It has also been used in much ONR-funded research.

In this project, we have implemented a number of improvements and updates to Ishmael. 


\section{Report Documentation Page}

Form Approved

OMB No. 0704-0188

Public reporting burden for the collection of information is estimated to average 1 hour per response, including the time for reviewing instructions, searching existing data sources, gathering and maintaining the data needed, and completing and reviewing the collection of information. Send comments regarding this burden estimate or any other aspect of this collection of information,

including suggestions for reducing this burden, to Washington Headquarters Services, Directorate for Information Operations and Reports, 1215 Jefferson Davis Highway, Suite 1204, Arlington

VA 22202-4302. Respondents should be aware that notwithstanding any other provision of law, no person shall be subject to a penalty for failing to comply with a collection of information if it

does not display a currently valid OMB control number.

1. REPORT DATE

30 SEP 2014

4. TITLE AND SUBTITLE

Next-Generation Bioacoustic Analysis Software

6. $\operatorname{AUTHOR}(\mathrm{S})$

7. PERFORMING ORGANIZATION NAME(S) AND ADDRESS(ES)

Oregon State University,2030 SE Marine Science

Drive,Newport,OR,97365

9. SPONSORING/MONITORING AGENCY NAME(S) AND ADDRESS(ES)

3. DATES COVERED

00-00-2014 to 00-00-2014

5a. CONTRACT NUMBER

5b. GRANT NUMBER

5c. PROGRAM ELEMENT NUMBER

5d. PROJECT NUMBER

5e. TASK NUMBER

5f. WORK UNIT NUMBER

8. PERFORMING ORGANIZATION

REPORT NUMBER

10. SPONSOR/MONITOR'S ACRONYM(S)

11. SPONSOR/MONITOR'S REPORT

NUMBER(S)

12. DISTRIBUTION/AVAILABILITY STATEMENT

Approved for public release; distribution unlimited

13. SUPPLEMENTARY NOTES

14. ABSTRACT

15. SUBJECT TERMS

16. SECURITY CLASSIFICATION OF:

a. REPORT

unclassified b. ABSTRACT

unclassified c. THIS PAGE

unclassified
17. LIMITATION OF ABSTRACT

Same as

Report (SAR)
18. NUMBER 19a. NAME OF

OF PAGES RESPONSIBLE PERSON

4

Standard Form 298 (Rev. 8-98) Prescribed by ANSI Std Z39-1 


\section{OBJECTIVES}

- Hire and train a software engineer to make improvements to Ishmael.

- Implement new audio I/O.

- Implement improved localization.

- Implement improved detection and classification.

- Implement improved acoustical measurements.

- Implement programming interfaces.

- Update Ishmael's documentation for these improvements.

- Create user group / web site for users to share information and tips.

\section{APPROACH}

The approach was to hire a software engineer to perform most of that above tasks in collaboration with myself. Research assistants will also perform much of the updating of documentation.

\section{WORK COMPLETED}

The software engineer, Jonathan (Jon) Dodge, was hired and started work on Ishmael in early December 2010. Unfortunately, Mr. Dodge, after learning many of the internal details of Ishmael and completing significant work on it, stopped showing up for work in late January 2013, despite repeated unreturned phone messages and emails. (Mr. Dodge had done a similar thing more briefly in August 2012, returning quite apologetic; after he returned, I told him he would terminated if it happened again and he said it would not happen again.) Consequently, his position was terminated in February.

As explained in last year's report, the software engineer hired to work on this project left in 2013, and I (Dave Mellinger) have been doing the software engineering for this project. As I have time to work on it only a small part of the time, work is going more slowly than planned, and this has necessitated nocost extensions for this project.

In late spring 2014, another project involving Ishmael, "Simple performance-characterized automatic detection of marine mammal sounds", was funded by the Navy's Living Marine Resources program. This project includes enough funding for software development that it became possible to combine those funds with funds from this project and hire a software engineer to complete both projects. Hiring is now underway, and the software developer is expected to start work shortly, in October 2014.

In the meantime, the following changes have been implemented:

- Kept Ishmael operating successfully on new releases of Windows (Windows 8 was particularly difficult) and MacOS.

- Added measurements to system for acoustical feature estimation of marine animal calls. These measurements are designed to work well in varying levels of noise. 
- Began implementation of a system for treating large collections of recorded files as a single, very long acoustic stream. Previously, Ishmael treated every sound file as a separate unit, instead of grouping them together into a single stream.

- Fixed a number of minor bugs.

\section{RESULTS}

Ishmael has several new features, most prominently the measurement system. Ishmael also continues to work on new releases of Windows and MacOS.

The new version of Ishmael has been built and made available to users. Work on the software is ongoing.

\section{IMPACT/APPLICATIONS}

Ishmael is used for marine mammal acoustic monitoring in many places around the world. Having the new features should make it more useful to researchers everywhere.

\section{TRANSITIONS}

The Navy's Living Marine Resources program is funding a project to transition Ishmael to fleet use. This will involve several steps, both in software development as well as in outreach: Ishmael will be enhanced to download detection configuration files across from an archive of such configuration files, and to display performance data for these configurations. Part of the project also involves teaching a number of tutorials/classes, done in collaboration with BioWaves, Inc., on using Ishmael for real-time monitoring of marine mammals.

\section{RELATED PROJECTS}

Advanced Methods for Passive Acoustic Detection, Classification, and Localization of Marine Mammals (award numbers N0001411IP20086 and N0001411WX21401). This ONR-funded effort is developing improved algorithms that will be offered to users in a user-friendly way by implementing them in Ishmael in the future.

Simple Performance-Characterized Automatic Detection of Marine Mammal Sounds (award number N39430-14-C-1434), funded by the Navy's Living Marine Resources program. Described above in the Transitions section.

\section{REFERENCES}

Fristrup, K.M. (1992). Characterizing Acoustic Features of Marine Animal Sounds. Technical Report WHOI-92-04, Woods Hole Oceanographic Inst., Woods Hole, Massachusetts.

Kandia, V., and Y. Stylianou. 2006. Detection of sperm whale clicks based on the Teager-Kaiser energy operator. Appl. Acoust. 67:1144-1163. 
Mellinger, D.K., R.P. Morrissey, S.W. Martin, L. Thomas, T.A. Marques, and J. Yosco. 2011. A method for detecting whistles, moans, and other frequency contours. J. Acoust. Soc. Am. 129:4055-4061. 